\title{
Fishing effects on diversity, size and community structure of the benthic invertebrate and fish megafauna on the Bay of Biscay coast of France
}

\author{
F. Blanchard ${ }^{1, *}$, F. LeLoc' ${ }^{2}{ }^{2}$ C. Hily ${ }^{2}$, J. Boucher ${ }^{1}$ \\ ${ }^{1}$ IFREMER, Ressources Halieutiques, BP 70, 29280 Plouzané Cedex, France \\ ${ }^{2}$ Université Bretagne Occidentale, LEMAR, UMR CNRS 6539, Technopôle Brest-Iroise, Place Nicolas Copernic, \\ 29280 Plouzané, France
}

\begin{abstract}
Within the framework of the 'dynamic equilibrium model', we tested the hypothesis that fishing causes major disturbance to benthic communities on deeper bottoms of the continental shelf. Benthic megafauna on the Bay of Biscay coast of France was sampled on fishing grounds subject to various conditions of exploitation. Samples were taken at around $100 \mathrm{~m}$ depth to avoid strong natural disturbances. Species diversity and the largest body mass class of invertebrates were smaller in strongly exploited areas than in moderately exploited ones. Biomass size spectra in strongly exploited areas were characterised by a comparatively large biomass of small invertebrates, hence the K-dominance curve of abundance was either above the biomass curve, or the curves intersected. In moderately exploited areas, the K-dominance biomass curves were above the abundance curves; the dominant species were a commercial species and a benthic species sensitive to the physical effects of the fishing gears. In the heavily exploited areas, the dominant species were opportunistic carnivorous species of minor or no commercial interest. There were no dominant fish species in the most strongly exploited areas, while 2 fish species were found in the moderately exploited areas. No fragile species were found in the most exploited areas, whereas 6 fragile species were found in the moderately exploited ones. It is concluded that the differences between the most strongly exploited and the moderately exploited areas were consistent with the hypothesis.
\end{abstract}

KEY WORDS: Benthic communities $\cdot$ Community dynamics $\cdot$ Disturbance $\cdot$ Diversity $\cdot$ Size spectrum

\section{INTRODUCTION}

International concern and systematic research on the physical effects of trawling on the seabed and on benthic communities date from the 1970s, after the rapid expansion of fishing fleets, accompanied by technological innovations. Fishing gear used to catch demersal fish and shellfish often disturb both the seabed and the organisms living within or on it. For the most part the response of benthic communities to fishing disturbance is consistent with the generalised model of disturbance, i.e. increased dominance of small, fastgrowing species, and general reductions in species diversity and evenness (Hall 1999).
However, not all communities are equally affected. The findings of empirical studies have not been consistent (Collie et al. 2000), mainly for 3 reasons: (1) nonlinearity of the diversity-disturbance relationship, (2) different levels of natural disturbance, (3) different spatial scales of the studies. Diversity is highest at intermediate levels of disturbance (Connell 1978). At low natural disturbance, the additional disturbance of fishing may lead to a diversity increase, whereas diversity may decrease when natural disturbance is intermediate, and it may remain unchanged when natural disturbance is high. Most studies have investigated the effects of fishing on benthic communities on the continental shelf at depths $<60 \mathrm{~m}$ in shallow seas of northern 
Europe and eastern North America (Collie et al. 2000). Benthic communities in these environments experience continuous disturbance at various scales, from a few centimetres in the case of bioturbation by infauna, through metre scales for feeding by predators on the seabed, up to large-scale natural disturbances such as seasonal storms, strong tidal currents, severe winters, or iceberg scouring (see Hall 1994 for a review). The intensity and frequency of natural disturbances therefore vary between the locations analysed. Effects of fishing disturbance on community structure and diversity are then not only likely to depend on the intensity and frequency of fishing, but also on the initial condition of the habitat (Jennings et al. 2002). The effects of trawling on infauna are more noticeable in areas where levels of natural disturbance are low (Brylinsky et al. 1994, Kaiser \& Spencer 1996), because in highdisturbance areas the community is already adapted to disturbance (Jennings \& Kaiser 1998). Finally, studies have to date been carried out at various spatial scales, but Kaiser (2003) has argued that detecting effects of fishing disturbance is strongly scale-dependent.

The dynamic equilibrium model of Huston (1994) provides a theoretical framework to analyse the effect of fishing disturbance on benthic communities and to reconcile apparently inconsistent findings. At a given productivity level, this model predicts that under conditions of high disturbance frequency and/or intensity, the few species present will be those that are able to complete their life cycles between disturbances and grow rapidly enough for their population size to recover. Under conditions of low disturbance, species whose life history is characterised by slow growth, late reproduction, large size, and efficient resource use will dominate the community. Diversity is then highest at intermediate levels of disturbance.

We conducted surveys on the Bay of Biscay coast of France at around $100 \mathrm{~m}$ depth to avoid interference of strong natural disturbances. Benthic megafauna, probably the most vulnerable part of the benthic communities directly impacted by fishing gears, was sampled on fishing grounds subject to different fishery impacts. If the dynamic equilibrium model holds true, then structural differences must be found between heavily fished and moderately fished communities. The following statements were tested: high fishing effort (1) reduces diversity and evenness, (2) reduces the observed maximum body mass, (3) favours a few body mass classes, (4) increases the steepness of the slope of number-size spectra, (5) shifts abundance and biomass distributions among species toward those typical of a disturbed community, (6) changes species composition.

\section{MATERIALS AND METHODS}

Sampling strategy. The study zone is located around $47^{\circ} \mathrm{N}$ and extends between 3 and $4^{\circ} \mathrm{W}$ off the western Atlantic coast of France (Fig. 1). A bottom trawl survey was carried out with RV 'Côtes de la Manche' during the last week of May and the first week of June 2001. A $2 \mathrm{~m}$ beam trawl was used to sample the invertebrate magafauna and demersal fishes (Kaiser et al. 1994, Jennings et al. 1999, Ellis et al. 2000). This proved to be an efficient method for large and rare species and for the integration of small-scale seabed patchiness (Frauenheim et al. 1989). The beam trawl was fitted with a chain mat and a $20 \mathrm{~mm}$ mesh liner. During sampling (20 min), warp length was 3 times water depth, the towing speed was 2 knots and the distance trawled was measured by the ship's differential GPS. A Reineck corer was used for sediment determinations. We sampled 8 stations within 4 areas around the $100 \mathrm{~m}$ isobath (about $2500 \mathrm{~m}^{2}$ per haul): 1 station in Area A, 3 in Area B, 2 in Area C, and 2 in Area D. Stratification was based on the spatial variations in the fishing effort of the bottom trawlers in the year of sampling (2001), as determined by ICES statistical rectangle, from data of the Fisheries Monitoring System of IFREMER; the

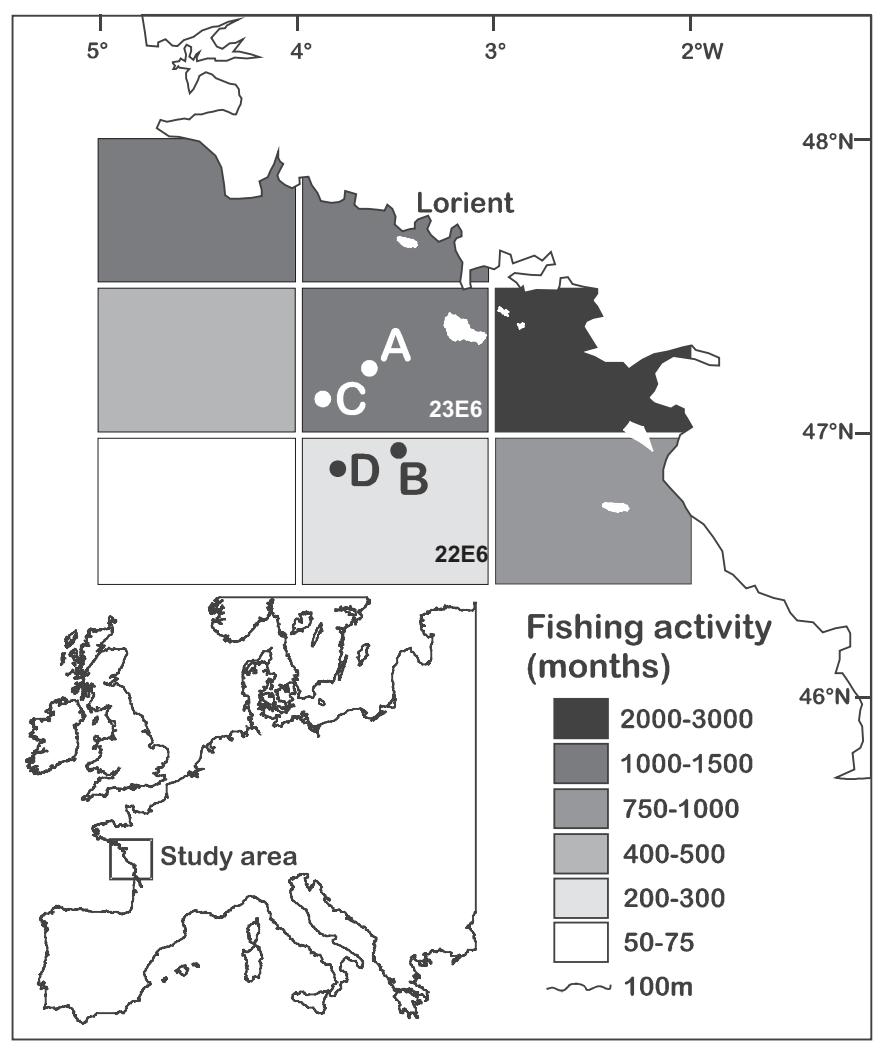

Fig. 1. Location of the 4 areas sampled in the Bay of Biscay and fishing effort of the bottom trawlers (in boat-months) in the ICES statistical rectangles for the year 2001, with $\mathrm{n}=1$ haul for $\mathrm{A}, \mathrm{n}=3$ for $\mathrm{B}$, $\mathrm{n}=2$ for $\mathrm{C}$ and $\mathrm{n}=2$ for $\mathrm{D}$ 
entire study zone is used by the fishery, i.e. unfished areas do not exist

Benthic fauna, invertebrates and fishes, were sorted, identified to the lowest possible taxonomic level (usually species), counted and weighed. The species biomass was determined in each sample as wet weight.

Faunal diversity. Species diversity is classically assessed with the species richness $S$, the Shannon-Wiener diversity index $H^{\prime}$ and the Pielou evenness index $J^{\prime}$. $S$ is the number of species. $H^{\prime}$ was calculated as:

$$
H^{\prime}=-\sum_{i=1}^{S} p_{i} \log p_{i}
$$

where $p_{i}$ is the abundance ratio of the species $i . J^{\prime}$ was calculated as follows:

$$
J^{\prime}=\frac{H^{\prime}}{\log S}
$$

The diversity indices N1 and N2 of Hill (1973) were also assessed, as they are less sensitive to the dominant species and to the sampling effort, respectively, than the previous ones (Lande 1996):

$$
\begin{aligned}
& \mathrm{N} 1=\exp \left(-\sum_{i=1}^{S} p_{i} \ln p_{i}\right) \\
& \mathrm{N} 2=\frac{1}{\sum_{i=1}^{S} p_{i}^{2}}
\end{aligned}
$$

Finally, indices of the taxonomic diversity $\Delta$ and distincness $\Delta^{*}$ (Warwick \& Clarke 1995) were assessed. These indices are less influenced by sample size than the other indices.

$$
\begin{gathered}
\Delta=\frac{\sum \sum_{i<j} w_{i j} x_{i} x_{j}}{\sum \sum_{i<j} x_{i} x_{j}+\sum_{i} x_{i}\left(x_{i}-1\right) / 2} \\
\Delta^{*}=\frac{\sum \sum_{i<j} w_{i j} x_{i} x_{j}}{\sum \sum_{i<j} x_{i} x_{j}}
\end{gathered}
$$

$\Delta$ is the average (weighted) path length between every pair of individuals, where $w_{i j}$ is the weight given to the path length linking species $i$ and $j$ in the hierarchical classification and $x_{i}$ denotes the abundance of the $i$ th species $(i=1, \ldots, S) . \Delta^{*}$ is the average (weighted) path length, ignoring paths between individuals of the same species. All the indices were calculated separately for each replicate tow, and results were tested for significant differences (ANOVA) between ICES statistical rectangles subject to high and low fishing effort.

Size structure of the macrobenthos. Trawling leads to mortality in benthic invertebrates and fishes, but the rates may be lower for the smallest individuals within and among species, as small organisms may be pushed aside by the pressure wave in front of the trawl (Gilkinson et al. 1998), or escape from the trawl through the mesh. Larger individuals usually suffer higher mortality when they are in the path of the trawl (Bergman \& van Santbrink 2000). Hence, fishing activity may change the community size spectrum structure (Rice \& Gislason 1996, Bianchi et al. 2000, Duplisea et al. 2002).

Biomass size spectra were constructed by summing individual biomass in body mass classes arranged on an octave scale, as in Platt \& Denman (1978). An increasing octave series means that the nominal weight for each class is double that of the previous one. Biomass size spectra were calculated for each area by pooling data from the respective stations. The normalised number-size spectra were determined by regressing, from the modal class to the largest one, the log of the total number in body mass class against the log of body mass class. The slopes of these regression lines characterise abundance trends across the size spectrum and simplify comparisons between areas (Sheldon et al. 1977, Pope \& Knights 1982, Sprules \& Munawar 1986, Pope et al. 1988). Differences among slopes were tested by ANCOVA.

Abundance-biomass comparison (ABC method). Combined K-dominance plots for species biomass and numbers may assume 3 possible forms, representing undisturbed, moderately disturbed and strongly disturbed macrobenthic communities (Warwick 1986, Warwick et al. 1987). A relative biomass curve above the relative numbers curve throughout its entire length is expected for undisturbed communities, where biomass is dominated by one or a few large species represented by few individuals. At moderate disturbance, the large competitively dominant species are eliminated, and the inequality in size between the numerically dominant species and the species with high biomass is reduced, so that biomass and number curves (in \%) are close and may intersect. As disturbance increases, communities become dominated numerically by one or a few small species. Then the abundance curve is above the biomass curve throughout its length.

Numbers and biomass curves of the most strongly exploited areas (A and C) were compared to the curves of the moderately exploited areas (B and D). The $W$ statistic (Clarke 1990) was calculated for each replicate tow separately and results were tested for significant differences (ANOVA) between ICES statistical rectangles subject to high and low fishing effort.

$$
W=\frac{\sum_{j=1}^{S}\left[\left(\sum_{j=1}^{i} b_{j}\right)-\left(\sum_{j=1}^{i} a_{j}\right)\right]}{50(S-1)}
$$

where $W$ is the standardised sum of the differences between each pair of species cumulative biomass 
$\left(\sum_{j=1}^{i} b_{j}\right)$ and cumulative abundance $\left(\sum_{j=1}^{i} a_{j}\right)$ value ranked in decreasing order.

Species composition. Biological and ecological characteristics of the species make it possible to group the species according to the potential impact of fishing. Such groups have been defined recently for invertebrates (ICES 2003): scavenger, opportunistic, fragile and sensitive species. Here we have grouped scavengers with opportunistic species and added one more group, the unaffected species. Scavengers have been found more frequently in recent years in the southern North Sea (Lindeboom \& de Groot 1998). Apart from possible climate effects, this can be attributed to the fishery impact, as discards and by-catch together with the crushed and broken animals provide large amounts of additional food to scavenging species on the sea floor. Scavengers migrate rapidly into areas of fishing disturbance, where they feed on animals damaged by trawls (Ramsay et al. 1996). Moreover, these species are often not injured by the passage of a trawl. Species with those characteristics sampled here were termed 'opportunistic species', e.g. Liocarcinus depurator and Munida bamffia. Some species are particularly sensitive to physical injury, as they are characterised by rigid bodies or tubes, and are sessile or slow-moving (MacDonald et al. 1996). Species with those characteristics were termed 'fragile species'; filter feeders were also part of this group, as they are sensitive to particles resuspended by the passage of the trawl, e.g. Leptometra celtica and Virgularia mirabilis. Species with a hard body that are not scavengers, and species that can escape from the haul after having been caught were termed 'unaffected species', e.g. Alphaeus glaber. Species not included in these groups may be affected, but less so than the fragile ones. These species were termed 'sensitive', e.g. Macropodia tenuirostris. The ratio (in species number) of fragile, sensitive, unaffected and opportunictic species as defined here were computed a priori for each sector and compared between ICES rectangles.

\section{RESULTS}

\section{Sediment characteristics}

According to the classification of the Bay of Biscay by Chassé \& Glémarec (1976), the sediments sampled correspond to the muddy sand and sandy mud type with a silt fraction between $10.0 \%$ at Stn C3 to $34.9 \%$ at Stn B3, and a median particle size between $109 \mu \mathrm{m}$ at Stn B3 to $201 \mu \mathrm{m}$ at Stn CC1 (Table 1). Sampling stations were in the depth range from 106 to $129 \mathrm{~m}$.
Table 1. Sediment characteristics of the sampling stations. Sediment type as defined in Chassé \& Glémarec (1976). FV: muddy sand; VS: sandy mud; SHV: heterogeneous muddy sand

\begin{tabular}{|lcccc|}
\hline Stn & $\begin{array}{c}\text { Depth } \\
(\mathrm{m})\end{array}$ & $\begin{array}{c}\text { Silt fraction } \\
<63 \mu \mathrm{m}(\%)\end{array}$ & $\begin{array}{c}\text { Median grain } \\
\text { size }(\mu \mathrm{m})\end{array}$ & $\begin{array}{c}\text { Sediment } \\
\text { type }\end{array}$ \\
\hline AA1 & 106 & 12.0 & 153 & $\mathrm{FV}$ \\
BB1 & 109 & 15.3 & 157 & $\mathrm{FV}$ \\
B2 & 109 & 32.5 & 115 & VS \\
B3 & 112 & 34.9 & 109 & VS \\
CC1 & 116 & 25.1 & 204 & SHV \\
C3 & 117 & 10.0 & 201 & FV \\
D1 & 129 & 11.8 & 169 & FV \\
DD1 & 118 & 12.4 & 186 & FV \\
\hline
\end{tabular}

\section{Fishing effort}

Apart from dredges that are used at depths greater than 50 to $60 \mathrm{~m}$, the only bottom trawl gears used in grounds of $100 \mathrm{~m}$ depth in 2001 were otter trawls. Fishing effort of the bottom trawlers was actually lower in Rectangle 22E6, with 299 month-boats, than in Rectangle 23E6, with 1242 month-boats. This is consistent with a previous analysis (Berthou et al. 2000), which showed that fishing effort in 1996 was lower in Rectangle 22E6 (between 130 and 590 month-boats) than in Rectangle 23E6 (between 1900 and 2800 month-boats). In Rectangles 22E6 and 23E6, 4 main 'métiers' (the association of a gear and a species or group of species) accounted for more than $60 \%$ of the activity. These were the Nephrops twin bottom trawls, the fish twin bottom trawls, the fish bottom otter trawls and the sole twin bottom trawls (Table 2). The reason why fishing effort was lower in Rectangle 22E6 was its greater distance from the main fishing harbour at Lorient, compared to Rectangle 23E6 (Fig. 1); most of the boats are rather small, so that costs increase with distance. The main species landed from Rectangles 22E6 and 23E6 are, in decreasing order: anchovy, horse mackerel, Norway lobster, hake, common sole, and cuttlefish. These 6 species represented $50 \%$ of the total landings from these areas in 2001.

\section{Faunal diversity}

Of the 58 species sampled in this study, 15 were fishes and 43 were invertebrates (Table 3). Differences between the most strongly exploited areas and the moderately exploited ones are shown in Table 4 . Although the species richness was greater in the moderately exploited areas (B and $\mathrm{D}_{\text {; }}$ between 22 and 33 species) than in the most strongly exploited ones (A and $\mathrm{C}_{i}$ between 13 and 23 species), the difference 
Table 2. Fishing effort in 2001 for the various 'métiers' (association of a gear, and a species or group of species) in ICES Rectangles 22E6 and 23E6 in number of months (number of boats). BOT: bottom otter trawl; TBT: twin bottom trawl. @ IFREMER, Fisheries Monitoring System

\begin{tabular}{|lcc|}
\hline Métier & $22 \mathrm{E} 6$ & $23 \mathrm{E} 6$ \\
\hline Bass BOT & 0 & $3(2)$ \\
Squid BOT & $1(1)$ & $21(7)$ \\
Horse mackerel BOT & 0 & $20(5)$ \\
Bream BOT & 0 & $11(3)$ \\
Fish BOT & $16(4)$ & $192(31)$ \\
Gadoid BOT & 0 & $9(4)$ \\
Pollack BOT & $1(1)$ & $3(3)$ \\
Nephrops BOT & $16(3)$ & $41(7)$ \\
Anglerfish BOT & $2(1)$ & 0 \\
Mackerel BOT & 0 & $23(7)$ \\
Hake BOT & $4(2)$ & $34(8)$ \\
Whiting BOT & 0 & $16(6)$ \\
Skate BOT & $2(1)$ & 0 \\
Gurnard BOT & $1(1)$ & $4(2)$ \\
Cuttlefish BOT & $14(4)$ & $48(14)$ \\
Sole BOT & $17(4)$ & $41(9)$ \\
Bass pair BOT & $1(1)$ & $1(1)$ \\
Nephrops pair BOT & 0 & $2(2)$ \\
Squid TBT & $4(1)$ & $4(3)$ \\
Fish TBT & $26(8)$ & $155(21)$ \\
Nephrops TBT & $133(35)$ & $495(67)$ \\
Anglerfish TBT & $11(3)$ & $23(5)$ \\
Hake TBT & $12(6)$ & $24(6)$ \\
Flatfish TBT & $1(1)$ & $2(2)$ \\
Cuttlefish TBT & $13(4)$ & $27(12)$ \\
Sole TBT & $24(12)$ & $43(21)$ \\
Total & $299(93)$ & $1242(248)$ \\
& & \\
& & \\
& &
\end{tabular}
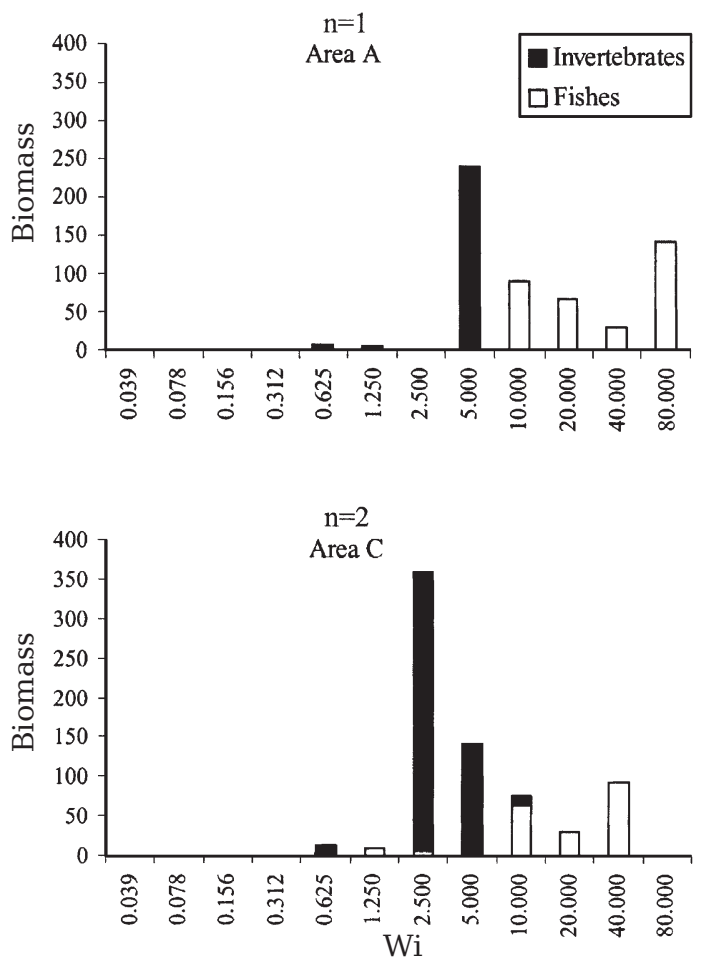

was not statistically significant (Table 5). There were no significant differences for evenness. On the other hand, diversity $H^{\prime}$ was significantly greater in the moderately exploited rectangle (0.97 to 1.15$)$, than in the strongly exploited one (0.68 to 0.89$)$. The same holds true with regard to the N1 index (2.64 to 3.16 in the moderately exploited rectangle, and 1.97 to 2.43 in the strongly exploited one), and the N2 index (5.9 to 9.99 in the moderately exploited rectangle, and 2.44 to 5.56 in the strongly exploited one). No significant differences were found for the indices $\Delta$ and $\Delta^{*}$.

\section{Size structure}

Biomass distribution was more similar to a Gaussian one in the moderately exploited areas (B and D) than in the most strongly exploited areas (A and $C_{i}$ Fig. 2). Biomass distributions in Areas $\mathrm{A}$ and $\mathrm{C}$ were characterised by a large contribution to the total biomass of one body mass class of invertebrates (5 and $2.5 \mathrm{~g}$, respectively). The largest observed body mass class for invertebrates in the moderately exploited areas (B and D) were 10 and $20 \mathrm{~g}$, respectively, while it was smaller in the most exploited areas (A and $C_{i} 5$ and $10 \mathrm{~g}$, respectively). The largest observed body mass class for fishes in areas (A, B, C and D) were 80, 20, 40 and $40 \mathrm{~g}$, respectively. There were no clear
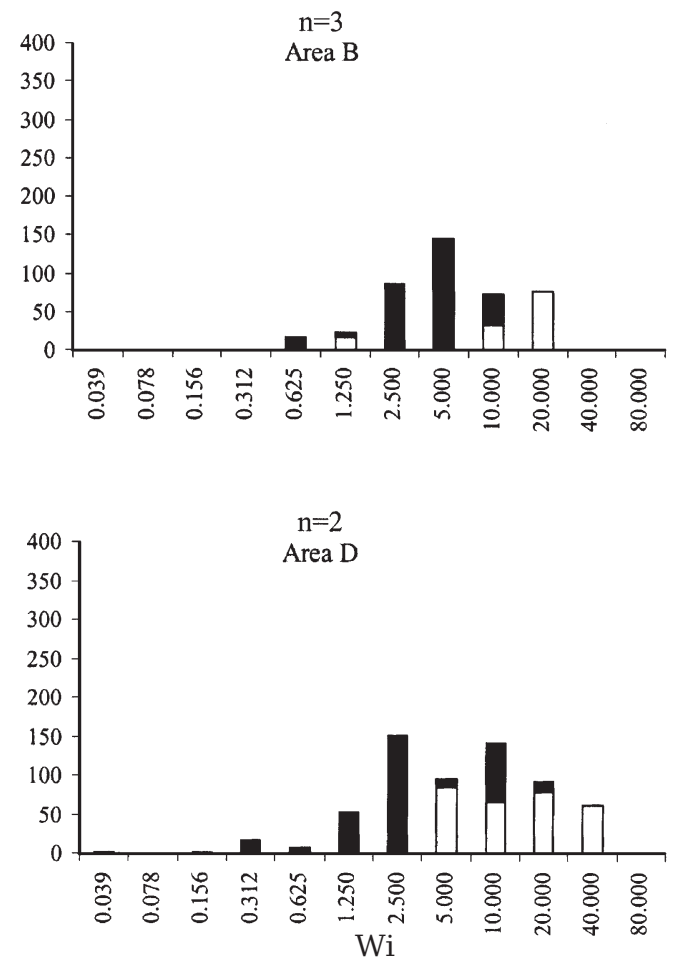

Fig. 2. Mean biomass size spectra for the benthic megafauna of invertebrates and fishes. Biomass and size classes (Wi) are in $\mathrm{g}$ wet weight. The number of hauls each panel is indicated above 
Table 3. List of species and their abbreviated codes, and taxonomic group (invertebrates [Inv] and fish), abundance (ind.) and biomass (wet weight in g per $1000 \mathrm{~m}^{2}$ ) in Areas A, B, C and D. SENS: sensitivity of invertebrates (except cephalopods) to physical effects of bottom fishing gears defined a priori; f: fragile; $s$ : sensitive; u: unaffected; o: opportunistic

\begin{tabular}{|c|c|c|c|c|c|c|c|c|c|c|c|}
\hline \multirow[t]{2}{*}{ Code } & \multirow[t]{2}{*}{ Species } & \multirow{2}{*}{$\begin{array}{l}\text { Taxon } \\
\text { group }\end{array}$} & \multicolumn{4}{|c|}{ Abundance } & \multicolumn{4}{|c|}{ Biomass } & \multirow[t]{2}{*}{ SENS } \\
\hline & & & $\mathrm{A}$ & B & $\mathrm{C}$ & $\mathrm{D}$ & $\mathrm{A}$ & $\mathrm{B}$ & $\mathrm{C}$ & $\mathrm{D}$ & \\
\hline $\mathrm{ACD}$ & Actinauges richardi & Inv & 0 & 0 & 0 & 0.55 & 0 & 0 & 0 & 12.47 & $\mathrm{~s}$ \\
\hline $\mathrm{ADP}$ & Adamsia carcinopados & Inv & 0 & 1.28 & 0 & 0.25 & 0 & 3.75 & 0 & 0.11 & $\mathrm{~s}$ \\
\hline ALD & Alcyonium digitatum & Inv & 0 & 0.12 & 0 & 1.78 & 0 & 0.48 & 0 & 0.49 & $\mathrm{f}$ \\
\hline ALGL & Alphaeus glaber & Inv & 0 & 8.19 & 3.32 & 4.33 & 0 & 6.9 & 2.28 & 2.75 & $\mathrm{u}$ \\
\hline $\mathrm{ALV}$ & Anapagurus laevis & Inv & 0 & 0 & 0 & 4.31 & 0 & 0 & 0 & 0.91 & $\mathrm{~s}$ \\
\hline AMU & Amphicteis gunneri & Inv & 0 & 0.91 & 1.52 & 0 & 0 & 0.01 & 0 & 0 & $\mathrm{~s}$ \\
\hline APE & Apporhais pespelicani & Inv & 0 & 0.25 & 0 & 0 & 0 & 0.51 & 0 & 0 & $\mathrm{u}$ \\
\hline ARLA & Arnoglossus laterna & Fish & 2.55 & 1.61 & 4.36 & 12.59 & 36.5 & 19.7 & 47.72 & 84.41 & \\
\hline ARSP & Argentina sphyraena & Fish & 0 & 0 & 0.38 & 0 & 0 & 0 & 1.91 & 0 & \\
\hline ASL & Astacilla longicornis & Inv & 0 & 0 & 0 & 7.73 & 0 & 0 & 0 & 0.56 & $\mathrm{~s}$ \\
\hline ASY & Astropecten spp. & Inv & 0 & 0 & 0 & 29.53 & 0 & 0 & 0 & 71.58 & $\mathrm{~s}$ \\
\hline BRLY & Brissopsis lyrifera & Inv & 0 & 0.41 & 0 & 0.55 & 0 & 5.27 & 0 & 1.38 & $\mathrm{f}$ \\
\hline CAAP & Capros aper & Fish & 0 & 0.5 & 1.32 & 0.25 & 0 & 1.43 & 4.03 & 0.97 & \\
\hline CALY & Callionymus lyra & Fish & 0.64 & 0.12 & 0.38 & 0 & 22.84 & 2.89 & 10.26 & 0 & \\
\hline CAMA & Callionymus maculates & Fish & 0 & 0 & 0.66 & 0.76 & 0 & 0 & 2.28 & 3.18 & \\
\hline $\mathrm{CAO}$ & Calliostoma granulatum & Inv & 0 & 0 & 0 & 1.85 & 0 & 0 & 0 & 7.6 & $\mathrm{u}$ \\
\hline CERU & Cepola rubescens & Fish & 0 & 0 & 0.33 & 0 & 0 & 0 & 7.87 & 0 & \\
\hline $\mathrm{CHCR}$ & Chlorotocus crassicornis & Inv & 0 & 1.82 & 0.38 & 1.64 & 0 & 3.32 & 0.79 & 1.86 & $\mathrm{~s}$ \\
\hline CRAL & Crangon allmanni & Inv & 5.11 & 6.91 & 5.35 & 1.27 & 5.64 & 6.3 & 5.1 & 0.77 & $\mathrm{~s}$ \\
\hline CUCU & Cuspidaria cuspidate & Inv & 0 & 0.25 & 0 & 0 & 0 & 0.22 & 0 & 0 & $\mathrm{~s}$ \\
\hline CUP & Phaxas pellucidus & Inv & 0 & 0 & 0 & 0.25 & 0 & 0 & 0 & 0.03 & $\mathrm{f}$ \\
\hline $\mathrm{D}$ & Dichelopandalus bonnieri & Inv & 0 & 0 & 0.38 & 0 & 0 & 0 & 0.47 & 0 & $\mathrm{~s}$ \\
\hline ENCI & Enchylopsus cimbrius & Fish & 1.28 & 2.32 & 0.33 & 1.6 & 43.75 & 74.5 & 16.79 & 46.04 & \\
\hline EUGU & Eutriglia gurnardus & Fish & 0.64 & 0 & 0 & 1.02 & 29.54 & 0 & 0 & 62.51 & \\
\hline GADI & Galathea dispersa & Inv & 0 & 0 & 0 & 1.02 & 0 & 0 & 0 & 0.01 & o \\
\hline GLR & Glycera rouxii & Inv & 0 & 0 & 0.38 & 0 & 0 & 0 & 0.01 & 0 & $\mathrm{~s}$ \\
\hline GORH & Goneplax rhomboids & Inv & 0 & 6.34 & 2.94 & 7.86 & 0 & 38.24 & 15.85 & 26.07 & $\mathrm{~s}$ \\
\hline GVU & Gaidropsarus vulgaris & Fish & 0 & 0.16 & 0 & 0 & 0 & 2.16 & 0 & 0 & \\
\hline HEMA & Heterocrypta maltzani & Inv & 0 & 0 & 0 & 0.55 & 0 & 0 & 0 & 0.22 & $\mathrm{~s}$ \\
\hline IND & Inachus dorsettensis & Inv & 0 & 0 & 0 & 0.25 & 0 & 0 & 0 & 1.2 & $\mathrm{~s}$ \\
\hline LEFR & Lesueurrigobius friesii & Fish & 1.28 & 7.37 & 3.17 & 0.25 & 2.64 & 18 & 7.25 & 0 & \\
\hline LID & Liocarcinus depurator & Inv & 14.68 & 13.04 & 9.35 & 2.4 & 144.84 & 61.75 & 94.86 & 0.67 & o \\
\hline LOPI & Lophius piscatorius & Fish & 0 & 0 & 0.38 & 0.51 & 0 & 0 & 5.29 & 0.61 & \\
\hline LWH & Lepidorhombus whiffiagonis & Fish & 0 & 0.33 & 0 & 12.29 & 0 & 4.67 & 0 & 36.17 & \\
\hline MAN & Macropodia tenuirostris & Inv & 0 & 1.28 & 0.38 & 20.24 & 0 & 1.29 & 0.01 & 10.97 & $\mathrm{~s}$ \\
\hline MATU & Macropipus tuberculatus & Inv & 0 & 0 & 0 & 1.31 & 0 & 0 & 0 & 5.03 & $\mathrm{o}$ \\
\hline MME & Merluccius merluccius & Fish & 0.64 & 0.49 & 1.8 & 1.27 & 87.67 & 0.68 & 77.11 & 43.08 & \\
\hline MUBA & Munida bamffia & Inv & 5.11 & 23.01 & 76.44 & 15.18 & 28.11 & 79.21 & 251.37 & 35.74 & o \\
\hline MVA & Microchirus variegatus & Fish & 3.19 & 1.78 & 1.09 & 3.67 & 52.83 & 27.57 & 21.25 & 56.3 & \\
\hline NEE & Nephthys caeca & Inv & 0 & 0.25 & 0 & 9.45 & 0 & 0.01 & 0 & 86.27 & $\mathrm{~s}$ \\
\hline NENO & Nephrops norvegicus & Inv & 7.02 & 29.62 & 23.84 & 0.55 & 66.83 & 196.27 & 135.65 & 1.21 & o \\
\hline NUSU & Nucula sulcata & Inv & 0.64 & 7.08 & 4.36 & 0.55 & 0.91 & 5.92 & 3.83 & 3.62 & $\mathrm{u}$ \\
\hline PAP & Pagurus pridauxi & Inv & 0 & 0.58 & 0 & 0.55 & 0 & 8.66 & 0 & 0.3 & o \\
\hline PEPH & Pennatula phosphorea & Inv & 0 & 0.25 & 0 & 2.28 & 0 & 0.13 & 0 & 0.56 & $\mathrm{f}$ \\
\hline POHE & Polybius henslowi & Inv & 0 & 0.41 & 0 & 28.48 & 0 & 4.31 & 0 & 1.7 & o \\
\hline POPU & Porania pulvillus & Inv & 0 & 0 & 0 & 0.25 & 0 & 0 & 0 & 4.2 & $\mathrm{u}$ \\
\hline POSP & Pontophilus spinosus & Inv & 0 & 0 & 0 & 0.51 & 0 & 0 & 0 & 1.07 & $\mathrm{~s}$ \\
\hline PRNO & Processa nouvelli & Inv & 0 & 1.49 & 0 & 0.55 & 0 & 0.36 & 0 & 1.58 & $\mathrm{~s}$ \\
\hline PTH & Pteria hirundo & Inv & 0 & 0 & 0 & 2.28 & 0 & 0 & 0 & 0.56 & $\mathrm{f}$ \\
\hline Scal. & Scalpellum spp. & Inv & 0 & 0 & 0 & 0.51 & 0 & 0 & 0 & 1.72 & $\mathrm{u}$ \\
\hline Sepiola & Sepiola spp. & Inv & 0 & 0.25 & 0.38 & 6.21 & 0 & 0.84 & 0.28 & 2.96 & \\
\hline SOME & Solenocera membranacea & Inv & 0 & 0 & 0 & 5.46 & 0 & 0 & 0 & 4.56 & $\mathrm{~s}$ \\
\hline SQDE & Squilla desmaresti & Inv & 0 & 0.66 & 1.47 & 0 & 0 & 2.19 & 4.74 & 0 & $\mathrm{o}$ \\
\hline STS & Sternaspis scutata & Inv & 0 & 0.37 & 0.33 & 0 & 0 & 0.59 & 0.25 & 0 & $\mathrm{~s}$ \\
\hline SVU & Solea vulgaris & Fish & 0.64 & 0 & 0 & 0 & 54.73 & 0 & 0 & 0 & \\
\hline TUC & Turritella communis & Inv & 0 & 0 & 0.38 & 0 & 0 & 0 & 0.42 & 0 & $\mathrm{u}$ \\
\hline VEOV & Timoclea ovata & Inv & 0 & 1 & 0.71 & 0 & 0 & 0.75 & 0.52 & 0 & $\mathrm{u}$ \\
\hline VIMI & Virgularia mirabilis & Inv & 0 & 0.5 & 0 & 0 & 0 & 0.96 & 0 & 0 & $\mathrm{f}$ \\
\hline
\end{tabular}


Table 4. Species richness $(S)$, Evenness index $\left(J^{\prime}\right)$, Shannon diversity index $\left(H^{\prime}\right)$, Hill diversity indices (N1 and N2), and taxonomic diversity and distincness indices $\left(\Delta\right.$ and $\left.\Delta^{*}\right)$ in each replicate of Areas A, B, C and D

\begin{tabular}{|lccccccc|}
\hline Stn & $S$ & $J^{\prime}$ & $H^{\prime}$ & N1 & N2 & $\Delta$ & $\Delta^{*}$ \\
\hline \multicolumn{7}{l}{ Strongly exploited } \\
AA1 & 13 & 0.8 & 0.89 & 2.43 & 5.56 & 3.77 & 4.19 \\
CC1 & 23 & 0.61 & 0.83 & 2.29 & 3.72 & 3.03 & 4.12 \\
C3 & 18 & 0.54 & 0.68 & 1.97 & 2.44 & 2.69 & 4.51 \\
\multicolumn{7}{l}{ Moderately exploited } \\
BB1 & 23 & 0.76 & 1.04 & 2.83 & 6.8 & 3.67 & 4.26 \\
B2 & 22 & 0.72 & 0.97 & 2.64 & 5.9 & 3.43 & 3.99 \\
B3 & 23 & 0.72 & 0.98 & 2.66 & 6.46 & 3.99 & 4.69 \\
D1 & 26 & 0.82 & 1.15 & 3.16 & 9.99 & 4.8 & 5.31 \\
DD1 & 33 & 0.76 & 1.15 & 3.16 & 8.54 & 4.16 & 5.02 \\
\hline
\end{tabular}

differences in maximal body mass for fishes between the most exploited areas (A and $\mathrm{C}$ ) and the moderately exploited areas (B and D) for fishes.

The fitted linear relationships between abundances and body mass explained a substantial proportion of the variance (Fig. 3). The $\mathrm{r}^{2}$ values were $0.8,0.92,0.89$ and 0.98, respectively, in Areas A, B, C and D. The steepest slope was in one of the most strongly exploited areas ( $\mathrm{C}:-1.62)$ while the flattest one was in a moderately exploited area (D:-1.26). However, there were no
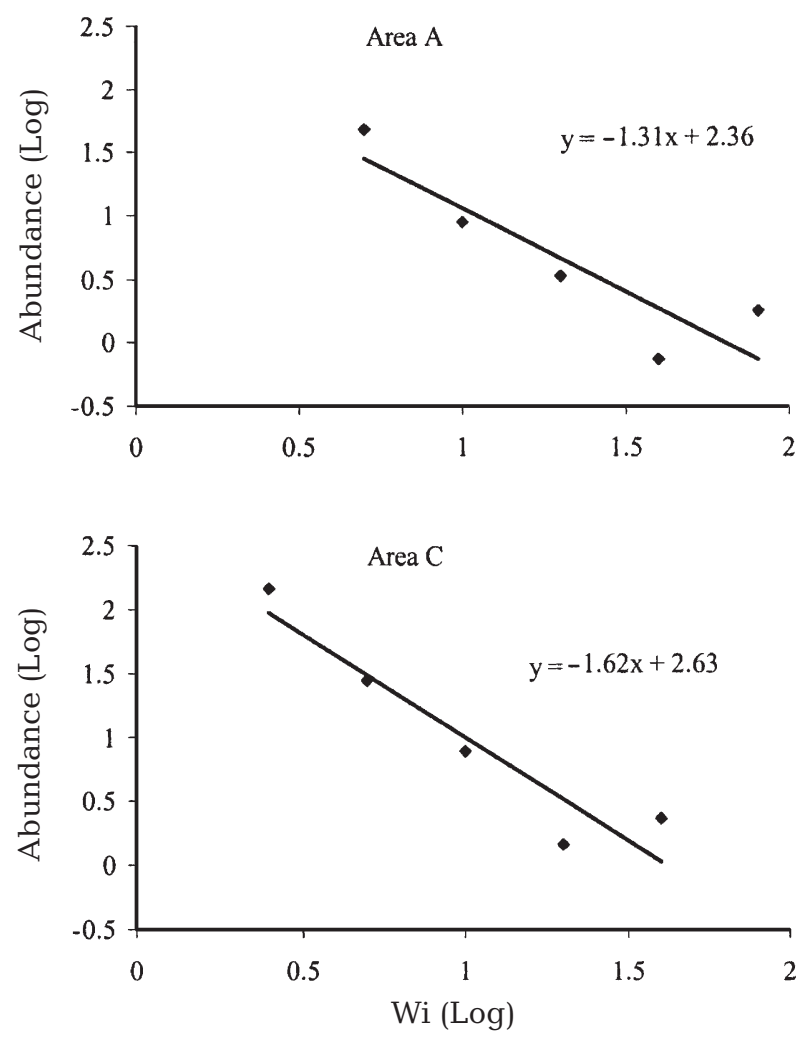

significant differences among slopes $\left(F_{\text {observed }}=0.38\right.$, $\left.v_{1}=3, v_{2}=14, F_{0.05}=3.34\right)$ or among intercepts $\left(F_{\text {observed }}=\right.$ $\left.0.07, v_{1}=3, v_{2}=14, F_{0.05}=3.34\right)$.

\section{Abundance-biomass comparison (ABC method)}

The communities in the moderately exploited areas (B and D) showed an undisturbed pattern with the biomass curve above the abundance curve (Fig. 4). On the other hand, the communities in the most strongly exploited areas (A and C) showed a disturbed pattern (abundance curve above the biomass curve) and a moderately disturbed pattern with (intersecting curves), respectively. The differences in the abundance/ biomass dominance curve between the 2 rectangles were significant (ANOVA, $W$ statistic: Table 5).

\section{Species composition}

Relative species abundance (Fig. 5) shows differences in dominance between the rectangles: 7 and 8 species, respectively, represent $>75 \%$ of the total abundance in Areas B and D, while only 5 and 4 species attain $75 \%$ in Areas $\mathrm{A}$ and $\mathrm{C}$. The most dominant species in Area B (moderately exploited) is the Norway
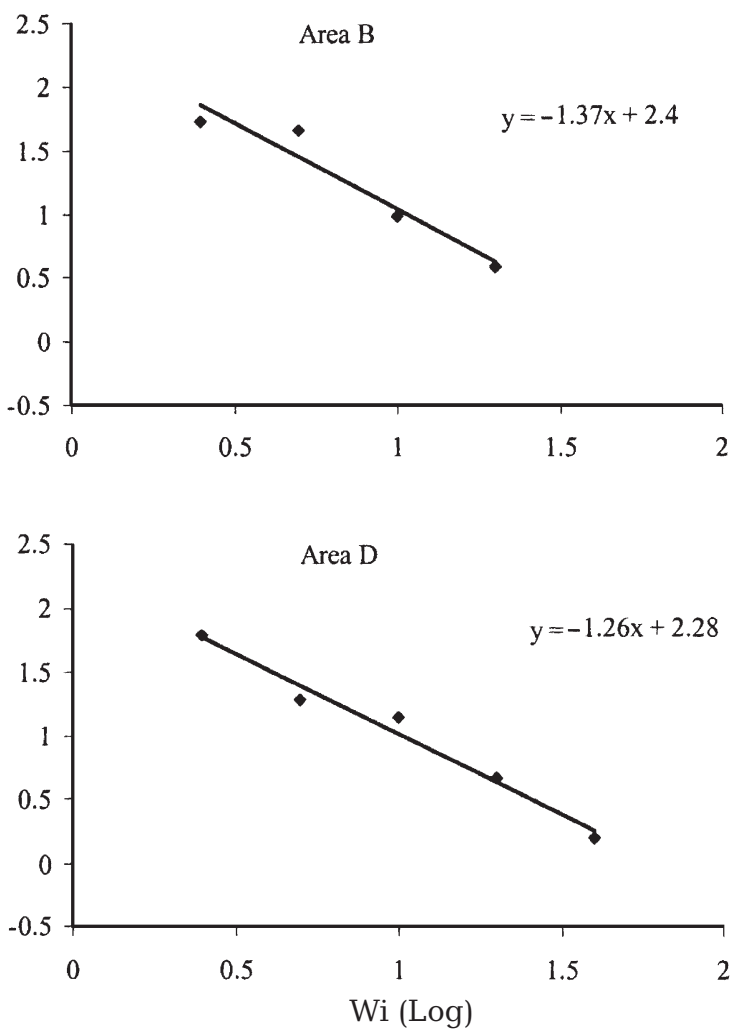

Fig. 3. Normalised size spectra for the benthic megafauna in the 4 areas: abundance vs wet weight (Wi) in $g$ 

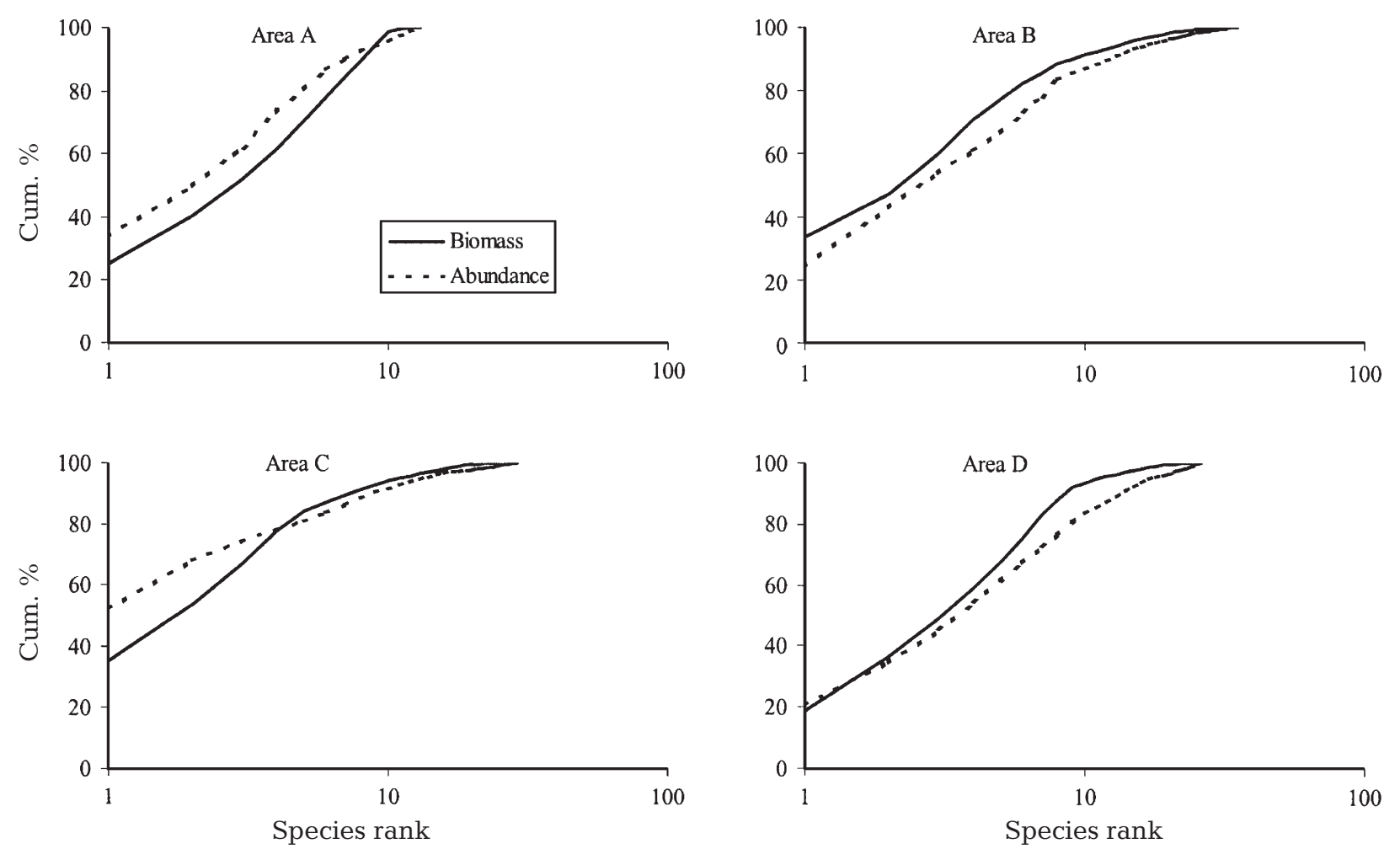

Fig. 4. Cumulative\% dominance curves in abundance and biomass of the benthic megafauna communities of fishes and invertebrates from the most exploited areas (A and C) and from the moderately exploited areas (B and D)
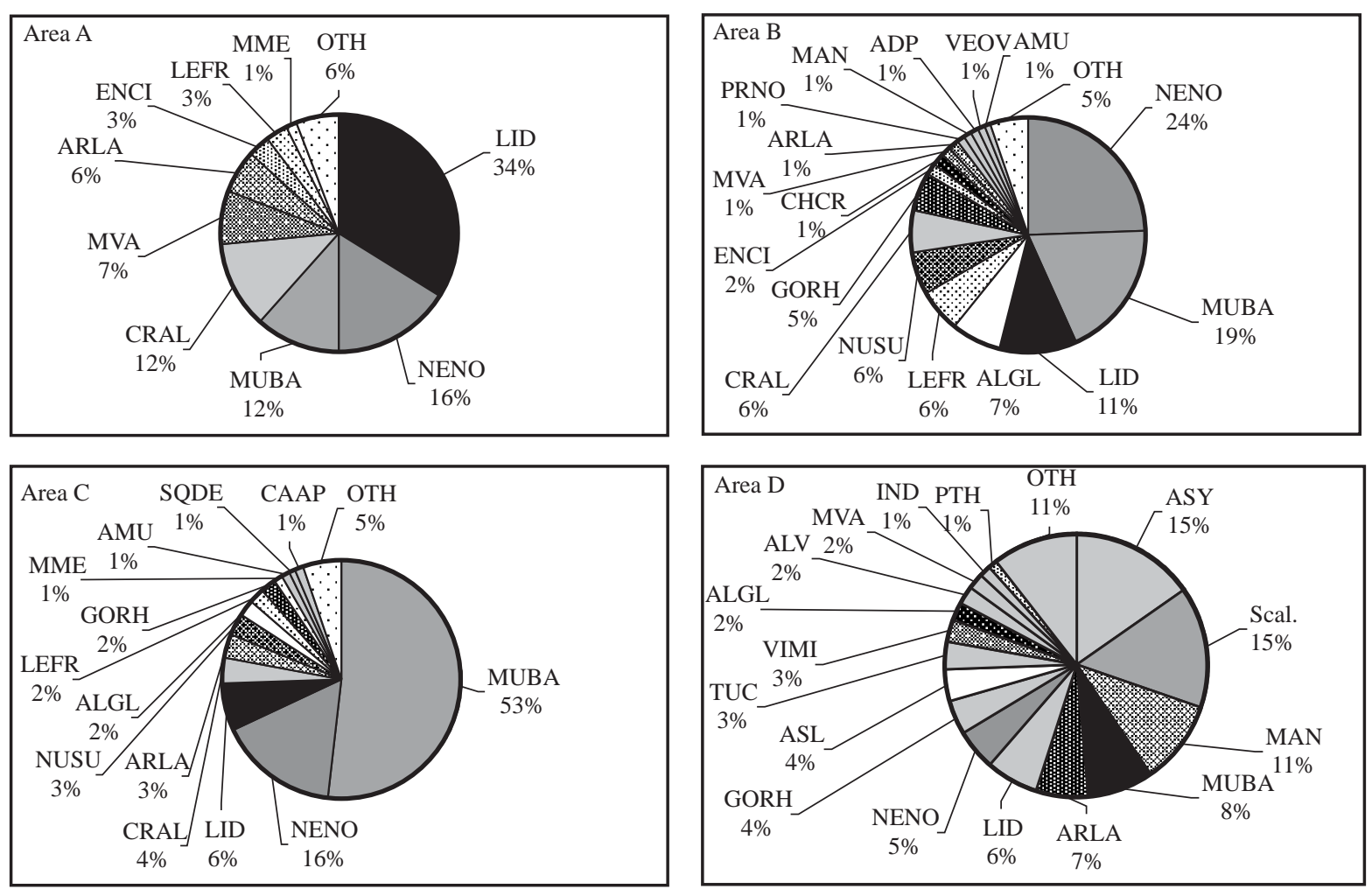

Fig. 5. Relative abundance of species. See Table 3 for the code significance of species (OTH: other species) 
Table 5. ANOVA of diversity indices $S, J^{\prime}, H^{\prime}, \mathrm{N} 1, \mathrm{~N} 2, \Delta_{,} \Delta^{*}$ and of the $W$ statistic of the abundance/biomass dominance curves, between rectangles with high and low fishing effort; *significant

\begin{tabular}{|lcl|}
\hline & $F$ & \multicolumn{1}{c|}{$\mathrm{p}$} \\
\hline$S$ & 4.096 & 0.073 \\
$J^{\prime}$ & 2.945 & 0.137 \\
$H^{\prime}$ & 13.75 & $0.01^{*}$ \\
$\mathrm{~N} 1$ & 13.03 & $0.011^{*}$ \\
$\mathrm{~N} 2$ & 9.087 & $0.024^{*}$ \\
$\Delta$ & 4.47 & 0.079 \\
$\Delta^{*}$ & 0.71 & 0.43 \\
$\mathrm{~W}$ & 15.009 & $0.0082^{*}$ \\
\hline
\end{tabular}

lobster Nephrops norvegicus, an opportunistic commercial species found in all areas of this study. In Area D (moderately exploited), the dominant species is a sensitive echinoderm genus (Astropecten spp.); Area D is the only one where this species was found. In the heavily exploited areas, the 2 dominant species are opportunistic carnivores, the blue-leg swimming crab Liocarcinus depurator in Area A, and Munida bamffia, a crustacean of minor commercial interest, in Area C. These 2 species were found in all areas of this study. There is no fish species within the first $75 \%$ of the total abundance in the most strongly exploited areas (A and C), while 2 small non-commercial fish species are found in the first $75 \%$ in the moderately exploited area: Fries's goby Lesueurigobius friesii and the scaldfish Arnoglossus laterna.

In the most strongly exploited areas (A and C), the opportunistic species were dominant in species number and fragile species were absent (Fig. 6), while sensitive species were dominant and some fragile species were present in the moderately exploited areas (B and D). However, ANOVA showed significant differences between the most strongly exploited areas (A and C) and the moderately exploited areas (B and D), only for fragile species (Table 6).

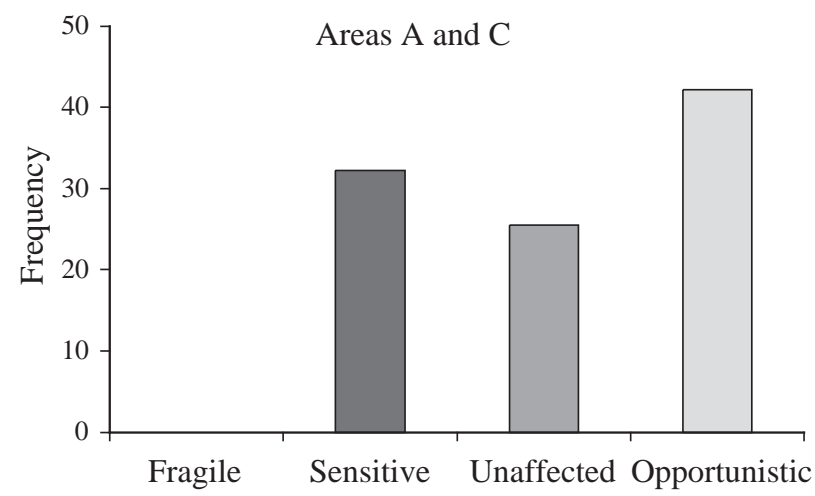

Table 6. Frequency of fragile, sensitive, unaffected and opportunistic species in the samples and ANOVA between the most exploited rectangle (Areas A and C) and the moderately exploited one (Areas B and D). ('Significant difference between rectangles, $\mathrm{H}_{0}$ rejected)

\begin{tabular}{|lcccc|}
\hline Stn & Fragile & Sensitive & Unaffected & Opportunistic \\
\hline AA1 & 0 & 20 & 20 & 60 \\
CC1 & 0 & 46.67 & 26.67 & 26.67 \\
C3 & 0 & 30 & 30 & 40 \\
BB1 & 6.25 & 43.75 & 12.5 & 37.5 \\
B2 & 12.5 & 37.5 & 18.75 & 31.25 \\
B3 & 15.79 & 47.37 & 21.05 & 15.79 \\
D1 & 13.64 & 45.45 & 22.73 & 18.18 \\
DD1 & 15 & 40 & 20 & 25 \\
F-value & 31.32 & 2.95 & 4.26 & 3.52 \\
p & $0.001^{*}$ & 0.137 & 0.085 & 0.11 \\
\hline
\end{tabular}

\section{DISCUSSION}

Sediment properties are factors influencing the benthic fauna (Basford et al. 1990, Kühne \& Rachor 1996, Rees et al. 1999), although the relationship is clearer for infauna than for the epifauna that was the focus in this study (Duineveld et al. 1991). Moreover, the sampling scale of a beam trawl is orders of magnitude larger than that of corers, so that small-scale heterogeneity is integrated (Callaway et al. 2002). To minimise these effects, benthic communities were only sampled on sandy mud and muddy sand. Furthermore, there are no hydrographic features or other environmental factors in this area that could lead to differential settlement of post-larval juveniles, so that fishing effort consitutes the major source of spatial variation.

However, sampling with bottom trawls usually implies high variance, due to a number of factors such as the patchy distribution of various species. Because of the limited sampling carried out in this study, 8 hauls might not have a representative species composition. Long-term surveys would be required to test the relia-

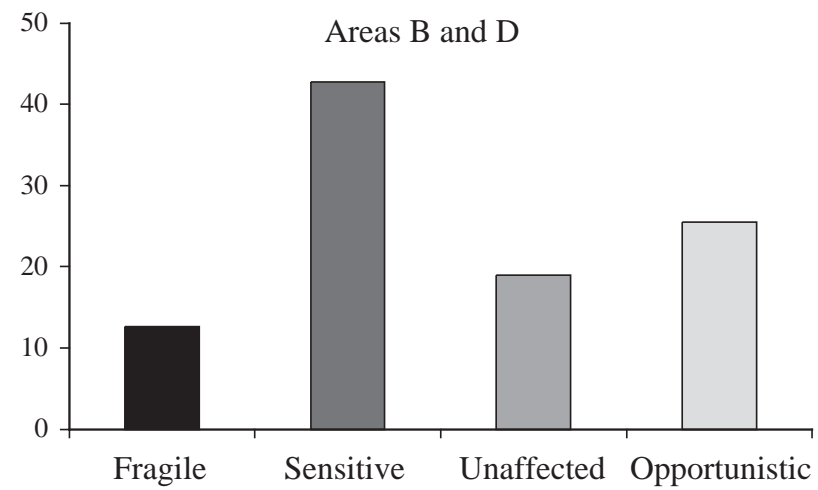

Fig. 6. Averaged frequency (in species number) of fragile, sensitive, unaffected and opportunistic species in the most exploited rectangle (Areas A and C) and in the moderately one (Areas B and D). See the text for the definition of these groups 
bility of the data, and caution is in order before generalising or extrapolating the results to the whole region. Our study is probably more useful in detecting patterns of change in community structure according to theoretical ecological guidelines, rather than in really testing an ecological hypothesis.

\section{Species diversity}

The diversity indices $H^{\prime}, \mathrm{N} 1$ and N2 confirmed the disturbance effect of fishing on the community. Results on species richness, evenness, taxonomic diversity and distinctness were less clear. Species diversity was lower where fishing disturbance was high, but it is difficult to conclude whether this is due to a decrease in slow growing sessile fauna and/or to avoidance of the vagile fauna, which is replaced by a few opportunist species. However, the numbers of both sessile and vagile fragile invertebrate species were lower in the most strongly fished areas (C. Hily pers. obs) so that both processes may apply. No differences were apparent from taxonomic indices; these indices are useful for macrofauna, but our study also included fish megafauna. Taxonomic distances between fishes and invertebrates are huge, compared to distances between invertebrate species, and the values of the taxonomic indices can be so high as to obscure the small spatial differences in taxonomic diversity of invertebrates. These indices should be computed separately for invertebrate and fish species.

\section{Size spectra}

Biomass size spectra are widely used to describe the structure of pelagic food chains, demersal fish communities and benthic communities of invertebrates, and sometimes related to the productivity of the ecosystems (Sheldon et al. 1977, Macpherson \& Gordoa 1996, Saiz-Salinas \& Ramos 1999). Normalised number-size spectra have been used to analyse the impact of fishing on demersal fish communities (Pope \& Knights 1982, Pope et al. 1988, Murawski \& Idoine 1992, Rice \& Gislason 1996, Bianchi et al. 2000), showing an increase in the abundance of the smallest body mass classes and a decrease in the largest ones, probably due to: (1) differential mortality, as fishing gears select large individuals; (2) release from predation of small individuals that are prey to the large ones; (3) recovery from continuous fishing mortality by species with early reproduction and fast growth ( $r$-strategists). Although there were no significant differences among slopes of the normalised number-size spectra, different biomass-size structures among areas were found, consis- tent with the previously quoted fishing effects on demersal fish communities: one small size class was dominant in the most exploited areas compared to the moderately exploited ones.

\section{Abundance-biomass comparison (ABC method)}

The ABC method (Warwick 1986) was originally designed to detect pollution effects on macrobenthic invertebrate communities, and then generalised to other physical and biological disturbances (Warwick et al. 1987) and applied to fishery impacts (Lindeboom \& de Groot 1998). The method was designed on the basis of the ecological succession theory: after a strong disturbance, (small) opportunistic species are the first to recolonise the habitat, and then (large) conservative species tend to replace them. The ABC method is rarely applied to fishing disturbances in megabenthic communities of invertebrates and fishes, and this study shows that the method can be applied to a wide range of individual sizes, taxa and disturbances. Our results support the hypothesis that fishing acts on communities like a physical disturbance, as well as the underlying theory of ecological succession. Only 3 discrete disturbance levels are defined in this method: highly disturbed, moderately disturbed and undisturbed, whereas in the dynamic equilibrium model, disturbance is a continuous variable. The intercalibration between a discrete variable of disturbance and a continuous one remains to be tackled.

\section{Species composition}

Dominant species in the moderately exploited areas were a commercial crustacean species and a sensitive echinoderm, while the dominant species in the most exploited areas were crustacean opportunistic carnivores of minor or no commercial interest. Fishing gear effects may favour scavengers and opportunistic carnivores attracted by crushed organisms, and eliminate fragile species. However, it remains unclear whether increases in scavenger abundance are the result of migration or of population growth. Commercial species such as Norway lobster may be depleted and replaced by a potential competitor such as Munida bamffia. Actually, the stock biomass of Nephrops norvegicus in the ICES Division VIIIa,b (Bay of Biscay) is at or near the lowest known level and this is attributed to the high exploitation rate and/or fishing patterns that cause high mortality in juveniles (ICES 2002).

We assumed that few differences in grain size of the sediment exist in the study area, so that no natural spatial variation was expected. However, Norway lobster 
is the dominant species in Area B, but not in Areas A, $\mathrm{C}$ and $\mathrm{D}$ (it is second in abundance in Areas A and $\mathrm{C}$, and the 7 th in the moderately exploited Area D). Relationships between Nephrops norvegicus density and sediment grain size have been shown for several stocks: density increases with particle size up to an optimum particle size value, then decreased for larger particle sizes; the optimum particle size differs between stocks (Afonso-Dias 1997). Moreover, the grain size range may be huge in some cases. The relationship between $N$. norvegicus density and particle size in the Bay of Biscay is unknown. It is therefore difficult to conclude whether the variation in the abundance rank of $N$. norvegicus is really a consequence of fishing or rather of small grain size variations or interactions between both factors. The sensitive species Astropecten is only dominant in Area D and is not found anywhere else. This could be due to interactions between small sediment variations and fishing effects. No fragile species were found in the most strongly exploited areas, while 6 species were observed in the moderately exploited ones, and this is more probably due to fishing effects than to sediment grain size. Moreover, there is no fish species among the first $75 \%$ of the total abundance in the most strongly exploited area, while 2 fish species are found among the top $75 \%$ in the moderately exploited area. Heavy fishing activity in the most exploited areas probably drives fishes out of the area.

\section{Community dynamics}

Indices of species diversity, size structure, and abundance-biomass distributions among species proved useful to demonstrate fishing impacts on the benthic communities at low and moderate levels of natural disturbance, when used in the framework of the dynamic equilibrium model.

Management requires quantitative methods that predict changes in communities. Size-based models (Duplisea et al. 2002) have to be designed. However available knowledge of trawling disturbance impacts is based primarily on empirical studies. Then models are only empirical, without strong theoretical underpinnings about the ecological processes involved in community dynamics, or with underpinnings not yet fully acknowledged by the scientific community. More theoretical works on community dynamics supported by empirical analyses are then needed to design convincing and effective management strategies of environmental impacts of fishing.

Community dynamics can theoretically be regulated by competitive interactions or ecological disturbances (including environmental and predation factors). Fishing effects as predation disturbance (removal of indi- viduals) have been hypothesised (Blanchard 2001). In communities regulated by interspecific interactions a high intensity of predation can alter the strength of competitive interactions and allow for increased coexistence of competitive species (Levine 1976, Vandermeer 1980). Fishing exploitation could have similar effects, i.e. benthic community dynamics under low conditions of exploitation and low or moderate levels of natural disturbance is probably regulated by competitive interactions, and fishing leads to a shift toward community dynamics regulated by fishing disturbance. This underscores the importance of analysing fishing effects as physical disturbances (break and crush effects of gears). Theories on community dynamics that include ecological disturbance, whether physical or predation disturbance, is a promising theoretical framework to analyse the effects of fishing.

\section{LITERATURE CITED}

Basford DJ, Eleftheriou A, Raffaelli D (1990) The infauna and epifauna of the northern North Sea. Neth J Sea Res 25: 165-173

Bergman MJN, van Santbrink JW (2000) Mortality in megafaunal benthic populations caused by trawl fisheries on the Dutch continental shelf in the North Sea in 1994. ICES J Mar Sci 57:1321-1331

Berthou P, Jézéquel M, Lespagnol P, Larvor S (2000) Répartition spatiale de la flotte de pêche française de Manche Atlantique en 1996. In: IRD (ed) Les espaces de l'halieutique. Actes du Quatrième Forum Halieumétrique, ENSA Rennes (France), 29 juin au 1er juillet 1999, Collection Colloques et Séminaires. IRD, Paris

Bianchi G, Gislason H, Graham K, Hill L and 7 others (2000) Impact of fishing on size composition and diversity of demersal fish communities. ICES J Mar Sci 57:558-571

Blanchard F (2001) The effect of fishing on demersal fish community dynamics: an hypothesis. ICES J Mar Sci 58: 711-718

Brylinsky M, Gibson J, Gordon DC (1994) Impacts of flounder trawls on the intertidal habitat and community of the Minas Basin, Bay of Fundy. Can J Fish Aquat Sci 51: $650-661$

Callaway R, Alsvag J, de Boois I, Cotter J and 8 others (2002) Diversity and community structure of epibenthic invertebrates and fish in the North Sea. ICES J Mar Sci 59: 1199-1214

Chassé C, Glémarec M (1976) Principes généraux de la classification des fonds pour la cartographie sédimentaire. J Rech Oceanogr 1:1-11

Clarke RC (1990) Comparisons of dominance curves. J Exp Mar Biol Ecol 138:143-157

Collie JS, Hall SJ, Kaiser MJ, Poiner IR (2000) A quantitative analysis of fishing impacts on shelf sea benthos. J Anim Ecol 69:785-798

Connell JH (1978) Diversity in tropical rain forests and coral reefs. Science 199:1302-1310

Duineveld GCA, Künitzer A, Niermann U, De Wilde PAWJ, Gray JS (1991) The macrobenthos of the North Sea. Neth J Sea Res 28:53-65

Duplisea DE, Jennings S, Warr KJ, Dinmore TA (2002) A size- 
based model of the impacts of bottom trawling on benthic community structure. Can J Fish Aquat Sci 59:1785-1795

Ellis JR, Rogers SI, Freeman SM (2000) Demersal assemblages in the Irish Sea, St George's Channel and Bristol Channel. Estuar Coast Shelf Sci 51:299-315

Frauenheim K, Neumann V, Theil H, Turkay M (1989) The distribution of the larger epifauna during summer and winter in the North Sea and its suitability for environmental monitoring. Senckenb Marit 20:101-118

Gilkinson K, Paulin M, Hurley S, Schwinghamer P (1998) Impacts of trawl door scouring on infaunal bivalves: results of a physical trawl door model/dense sand interaction. J Exp Mar Biol Ecol 224:291-312

Hall SJ (1994) Physical disturbance and marine benthic communities: life in unconsolidated sediments. Oceanogr Mar Biol Annu Rev 32:179-239

Hall SJ (1999) The effects of fishing on marine ecosystems and communities. Blackwell Science, Oxford

Hill MO (1973) Diversity and evenness: a unifying notation and its consequences. Ecology 54:427-432

Huston MA (1994) Biological diversity. The coexistence of species on changing landscapes. Cambridge University Press, Cambridge

ICES (2002) Report of the ICES Advisory Committee on Fishery Management. ICES CRR 255:835-838

ICES (2003) Report of the Working Group on Ecosystem Effects of Fishing Activities. Advisory Committee on Ecosystems. ICES CM 2003/ACE:05

Jennings S, Kaiser MJ (1998) The effects of fishing on marine ecosystems. Adv Mar Biol 34:201-352

Jennings S, Lancaster J, Woolmer A, Cotter J (1999) Distribution, diversity and abundance of epibenthic fauna in the North Sea. J Mar Biol Assoc UK 79:385-399

Jennings S, Nicholson MD, Dinmore TA, Lancaster JE (2002) Effects of chronic trawling disturbance on the production of infaunal communities. Mar Ecol Prog Ser 243:251-260

Kaiser MJ (2003) detecting the effects of fishing on seabed community diversity: importance of scale and sample size. Conserv Biol 17:512-520

Kaiser MJ, Spencer BE (1996) The effects of beam-trawl disturbance on infaunal communities in different habitats. J Anim Ecol 65:348-358

Kaiser MJ, Rogers SI, MacCandless DT (1994) Improving quantitative surveys of epibenthic communities using a modified $2 \mathrm{~m}$ beam trawl. Mar Ecol Prog Ser 106:131-138

Kühne S, Rachor E (1996) The macrofauna of a stony sand area in the German Bight (North Sea). Helgol Meeresunters 50:433-452

Lande R (1996) Statistics and partitioning of species diversity, and similarity among multiple communities. Oikos 76:5-13

Levine SH (1976) Competitive interactions in ecosystems. Am Nat 110:903-910

Lindeboom HJ, de Groot SJ (eds) (1998) The effects of different types of fisheries on the North Sea and Irish Sea

Editorial responsibility: Otto Kinne (Editor), Oldendorf/Luhe, Germany benthic ecosystems. Netherlands Institute of Sea Research, Texel

MacDonald DS, Little M, Eno C, Hiscock K (1996) Disturbance of benthic species by fishing activities: a sensitivity index. Aquat Conserv: Mar Freshw Ecosyst 6:257-268

Macpherson E, Gordoa A (1996) Biomass spectra in benthic fish assemblages in the Benguela System. Mar Ecol Prog Ser 138:27-32

Murawski SA, Idoine JS (1992) Multispecies size composition: a conservative property of exploited fishery systems? J Northwest Atl Fish Soc 14:79-85

Platt T, Denman K (1978) The structure of pelagic marine ecosystems. Rapp P-V Reun Cons Int Explor Mer 173:60-65

Pope JG, Knights BJ (1982) Comparison of length distributions of combined catches of all demersal fishes in surveys in the North Sea and at Faroe Bank. Can Spec Publ Fish Aquat Sci 59:116-118

Pope JG, Stockes TK, Murawski SA, Idoine SI (1988) A comparison of fish size composition in the North Sea and on Georges Bank. In: Wolff W, Soeder CJ, Drepper FR (eds) Ecodynamics, contributions to theoretical ecology. Springer-Verlag, Berlin, p 146-152

Ramsay K, Kaiser MJ, Hughes RN (1996) Changes in hermit crab feeding patterns in response to trawling disturbance. Mar Ecol Prog Ser 144:63-72

Rees HL, Pendle MA, Waldock R, Limpenny DS, Boyd SE (1999) A comparison of benthic biodiversity in the North Sea, English Channel, and Celtic Seas. ICES J Mar Sci 56:228-246

Rice J, Gislason H (1996) Patterns of change in the size spectra of numbers and diversity of the North Sea fish assemblage, as reflected in surveys and models. ICES J Mar Sci 53:1214-1225

Saiz-Salinas JI, Ramos A (1999) Biomass size-spectra of macrobenthic assemblages along water depth in Antarctica. Mar Ecol Prog Ser 178:221-227

Sheldon RW, Sutcliffe WH, Paranjape MA (1977) Structure of pelagic food chain and relationship between plankton and fish production. J Fish Res Board Can 34:2344-2353

Sprules WG, Munawar M (1986) Plankton size spectra in relation to system productivity, size and perturbation. Can J Fish Aquat Sci 43:1789-1794

Vandermeer JH (1980) Indirect mutualism: variations on a theme by Stephen Levine. Am Nat 116:441-448

Warwick RM (1986) A new method for detecting pollution effects on marine macrobenthic communities. Mar Biol 92:557-562

Warwick RM, Clarke KR (1995) New biodiversity measures reveal a decrease in taxonomic distincness with increasing stress. Mar Ecol Prog Ser 129:301-305

Warwick RM, Pearson TH, Ruswahyuni (1987) Detection of pollution effects on marine macrobenthos: further evaluation of the species abundance/biomass method. Mar Biol 95:193-200

Submitted: September 17, 2003; Accepted: June 1, 2004

Proofs received from author(s): September 28, 2004 